\title{
Solutrean and Magdalenian ferruginous rocks heat-treatment: accidental and/or deliberate action?
}

\author{
Hélène Salomon ${ }^{\mathrm{a},{ }^{*}}$, Colette Vignaud ${ }^{\mathrm{b}}$, Sophia Lahlil ${ }^{\mathrm{c}}$, Nicolas Menguy ${ }^{\mathrm{d}}$ \\ ${ }^{a}$ F.R.S.-FNRS, Service de Préhistoire, Université de Liège, Place du XX Août, 7, B-4000 Liège, Belgium \\ ${ }^{\mathrm{b}}$ C2RMF, UMR171 CNRS, Centre de Recherche et de Restauration des Musées de France, Palais du Louvre, Porte des Lions, 14 quai François Mitterrand, \\ FR-75001 Paris, France \\ ${ }^{c}$ Muséum National d'Histoire Naturelle, Département de Préhistoire, UMR 7194 MNHN, 1 rue RenéPanhard, FR-75013 Paris, France \\ d IMPMC, UPMC, 4 Place Jussieu, FR-75005 Paris, France
}

\section{A R T I C L E I N F O}

\section{Article history:}

Received 21 August 2014

Received in revised form

21 December 2014

Accepted 30 December 2014

Available online 9 January 2015

\section{Keywords:}

Goethite

Hematite

Heat-treatment

Paleolithic

Solutrean

Magdalenian

SEM-FEG

TEM-FEG

XRD

Combe Saunière

Les Maîtreaux

Blanchard

La Garenne

\begin{abstract}
A B S T R A C T
Heating of prehistoric coloring materials can induce radical changes in color indicative of structural matter transformation. For instance, the structure of the yellow iron oxide-rich mineral, goethite, changes into the red iron oxide-rich mineral, hematite, when it is heated to around $250-300{ }^{\circ} \mathrm{C}$. For a long time, heating has been thought to be the reason for the high frequencies of red rocks used in camp sites and the red pigments in rock art paintings. However, records of heat-treatment of coloring materials are usually not well documented; the contextual information is not clear enough to confirm intentional heating. Two Solutrean camp sites (the flint workshop Les Maîtreaux and the hunting site Combe Saunière I) and one middle Magdalenian cave with rock art (Grotte Blanchard, La Garenne) allow us to study the heating process of ferruginous rocks. All three sites, which have been excavated relatively recently, have well-defined archaeological records and strong associations between the ferruginous rocks and other artifacts. With the use of X-ray diffraction and electron $\mu$-diffraction for identifying structural modification and SEM-FEG and TEM-FEG for detecting dehydration nano-pores, we have strong evidence for intentional heat-treatment of yellow goethite-rich materials in two archaeological contexts and one site for unintentional heating, where rocks were only partially transformed. Intentional heating to obtain red hematite from primary goethite would have required ingenious methods of temperature control in fireplace settings and purpose-built ground ovens.
\end{abstract}

() 2015 Elsevier Ltd. All rights reserved.

\section{Introduction}

Processing coloring materials is rarely documented, although the final segment of the "chaîne opératoire", i.e. the use of pigment for rock painting, has been more widely studied. Refining our understanding of the socio-economical framework of Paleolithic hunter-gatherers, depends on an understanding of exploitation strategies and other behaviors and activities such as modification of the raw material. This paper focuses on a poorly understood aspect of Paleolithic behavior - the modification of coloring materials by heating.

\footnotetext{
* Corresponding author. Tel.: +32 (0)43665020; fax: +32 (0)43665551.

E-mail address: helene.salomon@ulg.ac.be (H. Salomon).
}

A. Leroi-Gourhan (Leroi-Gourhan, 1961), during his excavations of the Grotte du Renne at Arcy-sur-Cure, made the assumption that Châtelperronian people (last Neanderthals, ca 45-40 ky cal BP; Hublin et al., 2012) heated ferruginous rocks to modify the hue and experiment with color shades to produce different coloring materials. It is well known that yellow goethite takes on orange and red shades upon heating from 250 to $300{ }^{\circ} \mathrm{C}$. At these temperatures, goethite is transformed into hematite by dehydration. The redness becomes even more intense as the temperature and/or the heating time increases (Pomiès, 1997). Heat transformation of iron oxiderich yellow rocks has long been assumed to be the reason for the predominance of red materials at some archaeological sites, and for the spatial distribution of the wide range of hues found around fire places at sites such as Terra Amata (Lorblanchet, 1999; Wreschner, 1980), Qafzeh (Hovers et al., 2003; Godfrey-Smith and Ilani, 2004) and Skhul (d'Errico et al., 2010; Salomon et al., 2012), in the 
Epigravettian at Gontsy (Ukraine; Iakovleva and Djindjian, 2005), within the paintings at Lascaux (Dordogne, France; Pomiès et al., 1998a, 1999b), Altamira (Santander, Spain; Cabrera-Garrido, 1978; Couraud, 1987) and the Grande Grotte at Arcy-sur-Cure (Pomiès et al., 1999a; Baffier et al., 1999).

Mineral transformation has been investigated using synthetic and natural goethite by M. P. Pomiès (1997). It has been shown that the heating of ferruginous stones can be identified on the basis of different criteria. Systematic analyses of superficial color zonations and features in macroscopic blocks (e.g., brown to black zones, cracks, etc.) and spatial relationships of heat remains, may provide clues of heating. The micro-structure of the coloring materials is also a good indicator of heat treatment. X-ray powder diffraction pattern of hematite resulting from a heated goethite will display specific broadening of the peaks with typical relative intensity ratios (see Fig. 3 in Pomiès et al., 1998b). For instance, the diffraction lines [102], [104], [023] and [214] are wider whereas peaks [110], [116] and [300] remain narrow. As a consequence of the nonuniform broadening, the diffractogram shows a typical inversion of intensity of the [104] and [110] peaks. These diffraction patterns data were refined by the Rietveld method (Rietveld, 1969). Selective broadening of diffraction peaks appears to be related to disorder in the cationic sub-lattice, i.e. in the repeating array of $\mathrm{Fe}^{3+}$ (Pomiès et al., 1998b).

If a uniform broadening of diffraction peaks occurs, it is likely that the sample is natural and poorly crystallized. In contrast, nonuniform broadening can be an indicator of previous heating. Another indication of heat treatment can be seen in the dehydration pores of single crystals, whereby dehydration has induced topotactic transformation of hydroxide into oxide, changing goethite into hematite. When the dehydration-induced topotactic transformation occurs, the organization and shape of the dehydration pores is dependent on the size of the original crystal, temperature and duration of heating (Pomiès et al., 1999c). This can be observed with advanced microscopy techniques such as Transmission Electron Microscopy (Pomiès et al., 1999c).

M.P. Pomiès specified crystallographic features of a heated synthetic goethite-hematite and the criteria for identifying heated

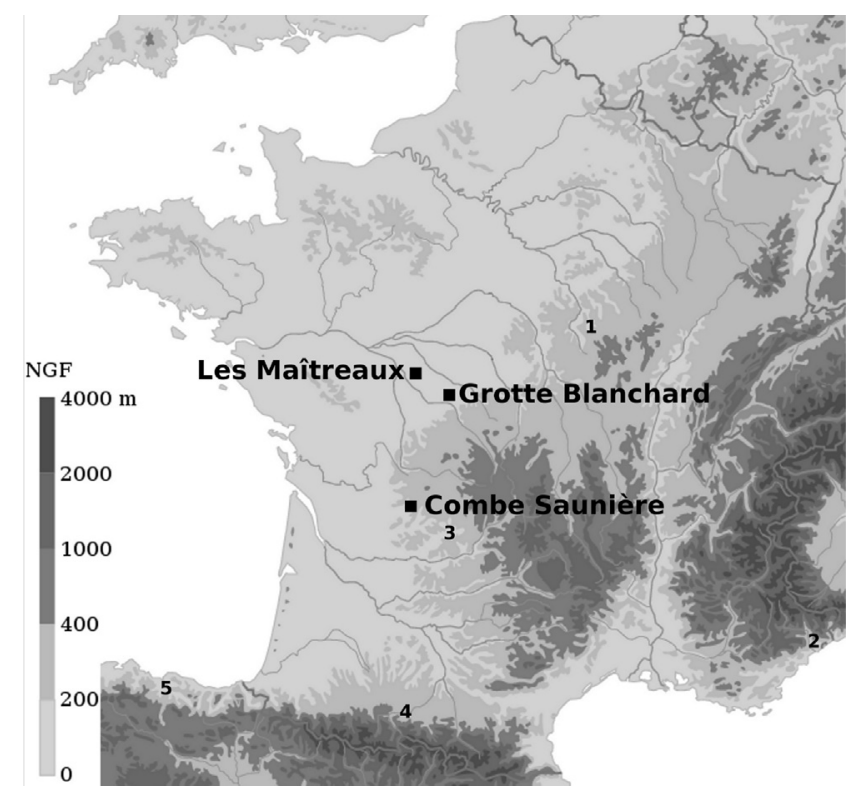

Fig. 1. Map of France showing locations of the 3 studied archaeological sites: Combe Saunière I, Les Maîtreaux, La Garenne. Sites cited in the text: 1/ Arcy-sur-Cure, 2/ Terra Amata, 3/ Lascaux, 4/ Troubat, 5/ Altamira. archaeological hematite. Through the investigation of microsamples of coloring materials, this analytical strategy was applied to the study of different Paleolithic sites showing:

1) Possible heat treatment of original goethite at the Pyrenean rock-shelter of the Moulin of Troubat where Magdalenian and Azilian inhabitants dwelt (Pomiès et al., 1999a);

2) Possible intentional heat treatment at the Mousterian grave site of the es-Skhul rock-shelter of long distance supplies of yellow goethite-rich lumps (Salomon et al., 2012; d'Errico et al., 2010);

3) there was no heat treatment applied to about one hundred pigments sampled from wall figures and cave deposits at the Lascaux cave site, indicative that the wide variety of hues used there during the Solutrean and Magdalenian were natural (Menu and Vignaud, 2006; Vignaud et al., 2006; Chalmin et al., 2004; Pomiès et al., 1999c, b; 1998a).

Additionally, an extensive study of all excavated coloring materials from the Chatelperronian levels of the Grotte du Renne at Arcy-sur-Cure showed that all coloring remains come from nonheated rocks obtained via specialized strategies for procurement of raw materials with various shades of color (Salomon et al., 2014, 2008; Salomon, 2009).

In this paper, we present results of the analyses of coloring material from three Paleolithic sites with different archaeological contexts (a Solutrean flint workshop and hunting station, and a Magdalenian occupation site with rock art). All three sites (Fig. 1), which have been recently excavated, have very good archaeological integrity and well-understood chronology. Furthermore, they have large quantities of coloring materials, essentially red, in welldefined contexts that help distinguish accidental and controlled heating for red materials.

\section{Overview of the three sites}

\subsection{Combe Saunière I}

The hunting camp-site in the Combe Saunière I cave (Sarliacsur-Isle, Dordogne), located near the confluence of the Isle and the Auvézère, was excavated from 1978 to 1996 (Chadelle et al., 1991). On the east of the site, sandy-clay tertiary deposits called "siderolithic" usually associated with many iron pisolites and fragments of ferruginous crust, outcrop on top of the plateau (Guillot et al., 1979) that we sampled and documented. The layer IV of Combe Saunière I contains a lithic industry of the Upper Solutrean. It is dated with ${ }^{14} \mathrm{C}$ to a period between 19000 and $20000 \mathrm{BP}$ (23 000-24 000 cal BP), contemporary with the last glacial maximum (Ducasse, 2012; Renard, 2011; Geneste and Plisson, 1986).

Layer IV yielded a variety of artifacts closely associated with faunal remains, especially abundant lithic spearheads (Solutrean shouldered points) and bone spearheads (with one or two longitudinal grooves) (Castel et al., 1998; Geneste and Plisson, 1986). The numerous spearheads are often damaged or broken as a result of use in hunting activities. In addition, the site is characterized by its abundance of red and black coloring materials, some with smoothed facets and/or with striations (Chalmin et al., 2006; Regert, 1995). It has no furniture or parietal art (Fig. 2). Five hundred and thirty eight blocks and fragments of coloring materials were identified in the well-defined Solutrean levels of Combe Saunière I: levels IVb and IVc. 'Blocks' are defined as nonfragmented coloring rocks which may have anthropogenic traces of use such as facets, grooves, striations or polished surfaces, or they may be 'raw' i.e. un-used. 'Fragment' is a generic term for blocks with natural or anthropogenic fractures. 


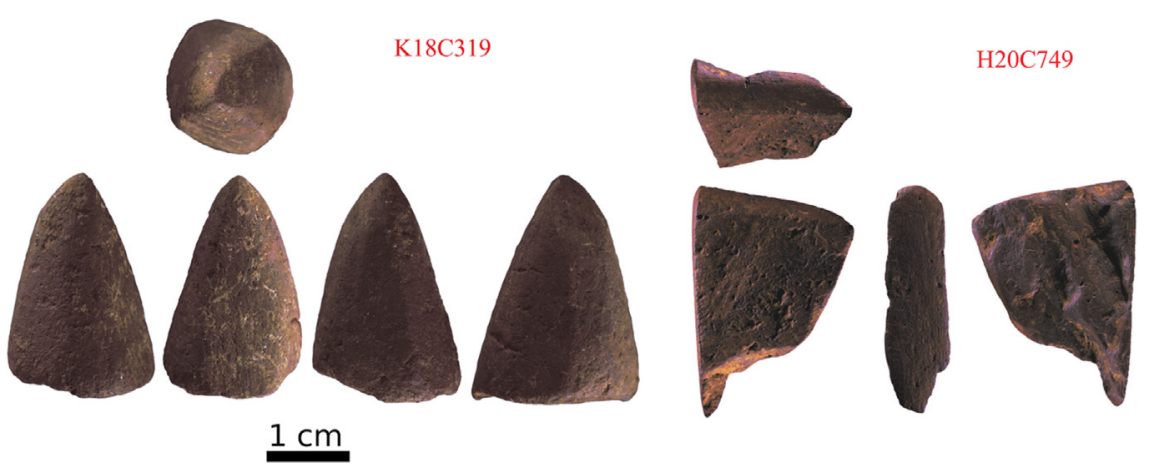

Fig. 2. Combe Saunière I: Two faceted hematite-rich blocks showing thin striations, partly smoothed.

\subsection{Les Maîtreaux}

The flint workshop site of Les Maîtreaux is located near the Claise river which carves a valley in the Upper Cretaceous and Eocene formations. Tertiary ferruginous crust and clay with pisolithes occur in the region on top of the limestone tables. The excavations of Les Maîtreaux, conducted by Thierry Aubry and Bertrand Walter from 1994 to 2004 in Bossay-sur-Claise (Indre-etLoire), uncovered several Solutrean open-air occupations. These had remains indicative of a Pressinien flint-flaking workshop for production of Laurel Leaves of various sizes, shouldered points and backed bladelets. The authors conclude that several activities were performed at the location of this workshop, and there was specific spatial organization (Aubry et al., 2004, 1998).

The deposit of Les Maîtreaux had significant concentrations of blocks and fragments of coloring materials covering an area of about $20 \mathrm{~m}^{2}$. Over one thousand are present, belonging to various petrographical types.

\subsection{Grotte Blanchard (La Garenne)}

The Grotte Blanchard (La Garenne, Saint Marcel, Indre), was discovered in 1956 by J. Allain during the Grand Abri exploration (Allain, 1957). It constitutes a reference site of the Middle Magdalenian called "à navettes" (Allain et al., 1985). Open to the south, on the right shore of the Creuse valley and at an elevation of $120 \mathrm{~m}$, the cave occurs in a Bajocian Jurassic limestone bench. In this limestone, which is naturally very cracked, archaeological material such as flint, bone and hard animal materials were found embedded in wall cracks. Wall paintings and carved stones were also present (Despriee et al., 2001). A study by Jezequel et al. (2011) and Jezequel (2001), provides a preliminary mineralogical and geochemical study of the cave wall paintings. The presence of numerous fireplace structures in the Grand Abri and the Grotte Blanchard suggests that the pigments may have been heated before use. This study investigates this possibility.

\section{Experimental methods}

\subsection{Classification and sampling strategy}

Following examination with low power magnification, Les Maîtreaux and Combe Saunière I collections (1021 and 538 pieces, respectively) were classified into petrological ranges with respect to their color, hardness, cohesion, recognizable mineral inclusions (nature, size, dispersion, and morphology), external and internal aspect (mat or bright, with metallic shimmer) and features (porosity, foliations, etc.) (Salomon et al., 2013). In the next stage of analysis, according to the spatial distribution, the state (raw block or fragment, piece with wear traces) and the petrological nature of the artifacts, each class was sampled to obtain asub-sample representative of the range of raw coloring materials present in the archaeological layers. They were carefully selected so that the diverse configurations of their spatial relationships with the other artifacts could be illustrated. Additional samples from the biggest blocks of one specific class concentrated in the same area in Les Maîtreaux were also analyzed.

All the samples were described using high magnification examination (SEM), elemental (EDX) and mineralogical analysis (XRD). TEM and thin section examination with petrographic microscopy was used for some samples. The results, which were interpreted according to the spatial distribution of the artifacts, showed several samples with heating stigmata.

Material from the Magdalenian levels of the La Garenne site, held in collections at the Argentomagus Museum, was sampled in 2010. Six artifacts of pure pigments with various aspects and colors were selected from the large collection of raw pigments. In addition, 31 objects with traces of pigment residues were sampled. The XRD and PIXE results of micro-analysis of pigments, either raw or on bone, are reported by Lahlil et al. (2014).

\subsection{Investigation of the nature and characteristics of crystalline phases using XRD and non destructive $\mu-X R D$}

In addition to the traditional X-ray diffraction (XRD) device (Siemens D5000, cobalt anode Co K- $\alpha, 2 \theta$ between 10 and $80^{\circ}$, acquisition time between 2 and $12 \mathrm{~h}$ ), which requires a significant amount of material ground into powder, a new non-invasive micro$\mathrm{X}$-ray diffraction ( $\mu$-XRD) device was used to identify the crystalline phases present in the blocks of coloring materials. This apparatus, developed by the C2RMF laboratory, provides high-quality diffractograms and can be used for analysis of small-sized particles. The diffractograms are recorded in $2 \theta$ from 5 to $60^{\circ}$ with a copper anode $(\mathrm{Cu} \mathrm{K}-\alpha)$. The Fit2D software is used to process the diagrams, and the EVA software for the assignment of the diffraction lines (de Viguerie et al., 2009).

\subsection{Investigation of the crystal morphology using SEM-FEG and TEM-FEG observations}

The investigation of crystal morphology relies on the use of Scanning Electron Microscopy (SEM) with a tungsten filament, or a field emission gun (SEM-FEG) and Transmission Electron Microscopy (TEM) with a LaB6 filament or a field emission gun (TEMFEG). Each device is coupled to an X-ray energy dispersive analyzer (EDX) allowing the elemental chemical analysis of the observed zone. 
The experimental conditions are as follows: raw blocks or micro-samples are examined under vacuum without special preparation with the Philips SEM XL30 of the C2RMF Laboratory under a voltage acceleration of 5 at $10 \mathrm{kV}$ to avoid charging effects; the Xray energy dispersive analyses (EDX) are performed under $20 \mathrm{kV}$. Samples containing crystals smaller than one micrometer were also studied with the SEM-FEG (Geminiultra TM55, Carl Zeiss instruments) of the Laboratoire Interfaces et Systèmes Electrochimiques (LISE) facility, at the CNRS-Paris VI. Using an acceleration voltage of $5 \mathrm{kV}$ or $10 \mathrm{kV}$ and a $2.3 \mathrm{~mm}$ working distance and application of gold coatings, these settings enable examination of material up to 200000 magnification.

Transmission Electron Microscopy (TEM-FEG), which requires special preparation, is particularly effective for examining very thin crystal aggregates, as it can distinguish the internal crystallographic structure as grain boundaries and twins, precipitates and internal nano-pores of single crystals with high definition. A Jeol $2100 \mathrm{~F}$ microscope of the Institut de minéralogie et de physique des milieux condensés (IMPMC) set at $200 \mathrm{kV}$ was used, coupled with an EDX spectrometer (PGT- PRISM 2000 equipped with the IMIX software) with a $1 \mathrm{~nm}$ beam size and a $300 \mathrm{~s}$ acquisition time. Particle size was analyzed using the standard analysis software for processing digital images (Gatan Digital Micrograph, Scion Image) and electron diffraction patterns were indexed with the CaRIne Cristallography software. Such patterns permit differentiation of hematite from goethite (hexagonal or orthorhombic structure, respectively); this cannot be done using elemental analysis.

\section{Results and discussions}

\subsection{Combe Saunière I: accidental heat treatment?}

In Combe Saunière I, macroscopic and petrographic observations as well as XRD analysis indicate that most of the collection of coloring material consists of a natural mixture of hematite, goethite and quartz (442 blocks). These have the same features as the ferruginous pisolithes and concretions we collected from the top of the plateau (Salomon, 2004; Salomon et al., 2013). Red blocks are in class 1, whereas the yellow-brownish blocks are in class 2 (Tables 1 and 2). However, three blocks of brownish to red coloring material have micro-cracks on their surface suggesting that they may have undergone a heat-treatment.

The X-ray diffraction patterns of class 1 and class 2 artifacts show a natural mixture in various proportions of quartz and, respectively, hematite or goethite. The three brownish to red blocks (class 1 and 2) yield different diffractograms. The powders sampled at the external surface of the three blocks show the coexistence of a

Table 1

Combe Saunière I: list of laboratory labels attributed to analyzed artifacts according to petrological class, with indication of square meter.

\begin{tabular}{lll}
\hline Combe Saunière 1 & Square & Class \\
\hline CS01 & H20C & 1 \\
CS02 & I18A & 1 \\
CS03 & K17D & 1 and 2 \\
CS04 & K18C & 1 \\
CS05 & I17 & 1 \\
CS06 & J16A & 1 and 2 \\
CS07 & J18B & 1 \\
CS08 & K18C & 1 and 2 \\
CS09 & H20D & 2 \\
CS10 & I17A & 2 \\
CS11 & I18A & 2 \\
CS12 & I18A & 2 \\
CS13 & K14A & 2 \\
\hline
\end{tabular}

Table 2

Combe Saunière I: Assemblage sampling and analysis according to petrological class.

\begin{tabular}{|c|c|c|c|c|}
\hline Combe Saunière 1 & $\begin{array}{l}\mathrm{Nb} \text { of } \\
\text { objects }\end{array}$ & $\begin{array}{l}\text { Hematite- } \\
\text { (goethite-)rich } \\
\text { concretions (1) }\end{array}$ & $\begin{array}{l}\text { Geothite-rich } \\
\text { concretions (2) }\end{array}$ & $\begin{array}{l}\text { Manganese } \\
\text { oxides (3) }\end{array}$ \\
\hline $\begin{array}{l}\text { Macro- and } \\
\text { mesoscopic } \\
\text { observation }\end{array}$ & 538 & 442 & 42 & 54 \\
\hline XRD & $\begin{array}{l}13 \text { (14 } \\
\text { samples) }\end{array}$ & 8 & 5 & \\
\hline Sample labels & - & $\begin{array}{l}\text { CS01-CS08 with } \\
\text { CS03i and CS03e }\end{array}$ & CS09-CS13 & \\
\hline TEM & 4 & 4 & & \\
\hline Sample labels & - & $\begin{array}{l}\text { CS03e, 03i, 05, } 06 \\
\text { and CS08 }\end{array}$ & & \\
\hline
\end{tabular}

hematite phase with non-uniformly broadened diffraction peaks and a maghemite phase (Table 3; Fig. 3a). On the contrary, the internal part of these blocks contains only goethite and quartz. Electron diffraction patterns confirmed the presence of an internal phase of goethite, and a hematite phase on the external part of the blocks. The 1.5-10 nm large longitudinal dehydration nano-pores found in the hematite crystals clearly show a dehydration process (Fig. 3b and c). Moreover, the maghemite phase confirms heating in direct contact with organic materials. It is likely that, exposed to a moderate temperature (estimated $<350{ }^{\circ} \mathrm{C}$ ), these blocks have been heated. Only surfaces were affected and superficial red hematite crystals formed. The presence of some maghemite indicates that the blocks could have been in contact with wood and food fats in a fireplace (Nørnberg et al., 2004; Grogan et al., 2003; Schwertmann and Cornell, 2000; Cornell and Schwertmann, 1996). Since block surfaces could have been blackened simply by being close to burning organic material (Pomiès, 1997; Audouin and Plisson, 1982), and there are no traces of use, such as facets, smoothed surfaces, scars or striations, the heat treatment was probably not intentional. It is therefore conceivable that these blocks were either very close to an active fireplace or left in a fireplace when it was extinguished but still hot.

\subsection{Les Maîtreaux}

\subsubsection{Spatial distribution of coloring materials}

The artifacts were identified and distributed in five different classes based on their macroscopic, petrographic and mechanical characteristics (Tables 4 and 5; Salomon et al., 2013; Salomon, 2009):

- Class A: almost pure iron oxide-rich blocks and sharp fragments which are cavernous, red to black, and have a medium hardness of 3 on the Mohs scale and an uneven compactness. All specimens (501 pieces) are concentrated in squares N14, M13 and M14 (Fig. 4);

- Class B: soft goethite, yellow, rounded pieces, concentrated in the $\mathrm{S}-\mathrm{W}$ of square $\mathrm{N} 19$ (46 pieces);

- Class C: pink ferruginous sandstone with rounded quartz grains, concentrated in the $\mathrm{N}-\mathrm{E}$ of square $\mathrm{N} 19$ (51 pieces);

- Class D: multi-hue blocks and fragments (yellow, orange, red and black with metallic shimmer) of ferruginous sandstone more or less rich in sub-angular quartz grains, medium hardness, spread over a large area with two flint concentrations (186 pieces);

- Class E: dark red, soft, porous, homogeneous and clayey blocks and fragments showing yellow, red and black minerals at low magnification, spread over the same area as class D artifacts (237 pieces) - three refits were possible and two pieces had micro-striations with polish. 
Table 3

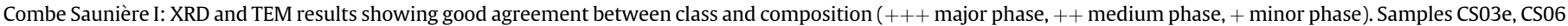
and CS08 show non uniform broadening of hematite $(\mathrm{H})$ peaks, a minor phase of maghemite and the presence of goethite $(\mathrm{G})$ inside $\mathrm{CSO3}$ sample.

\begin{tabular}{|c|c|c|c|c|c|c|c|}
\hline \multirow[t]{2}{*}{ Combe Saunière 1} & \multicolumn{4}{|l|}{ XRD } & \multicolumn{3}{|l|}{ TEM } \\
\hline & Hematite & Goethite & Maghemite & Quartz & Non uniform broadening & Crystal morphology & Pores \\
\hline CS01 & +++ & & & + & & & \\
\hline CSO2 & +++ & & & & & & \\
\hline CS03e & +++ & + & + & +++ & Yes & Pseudo acicular and massive & Longitudinal and spherical 5-20 nm \\
\hline CSO3i & & +++ & & +++ & & Massive and acicular & \\
\hline CS04 & +++ & & & + & & & \\
\hline CS05 & +++ & & & ++ & & & \\
\hline CS06 and CS08 & +++ & & + & ++ & Yes & Pseudo acicular & Longitudinal and spherical 5-20 nm \\
\hline CS07 & +++ & & & + & & & \\
\hline CS09 & + & +++ & & & & & \\
\hline CS10 & & +++ & & & & & \\
\hline CS11 & + & +++ & & & & & \\
\hline CS12 & + & +++ & & +++ & & & \\
\hline CS13 & & ++ & & + & & & \\
\hline
\end{tabular}

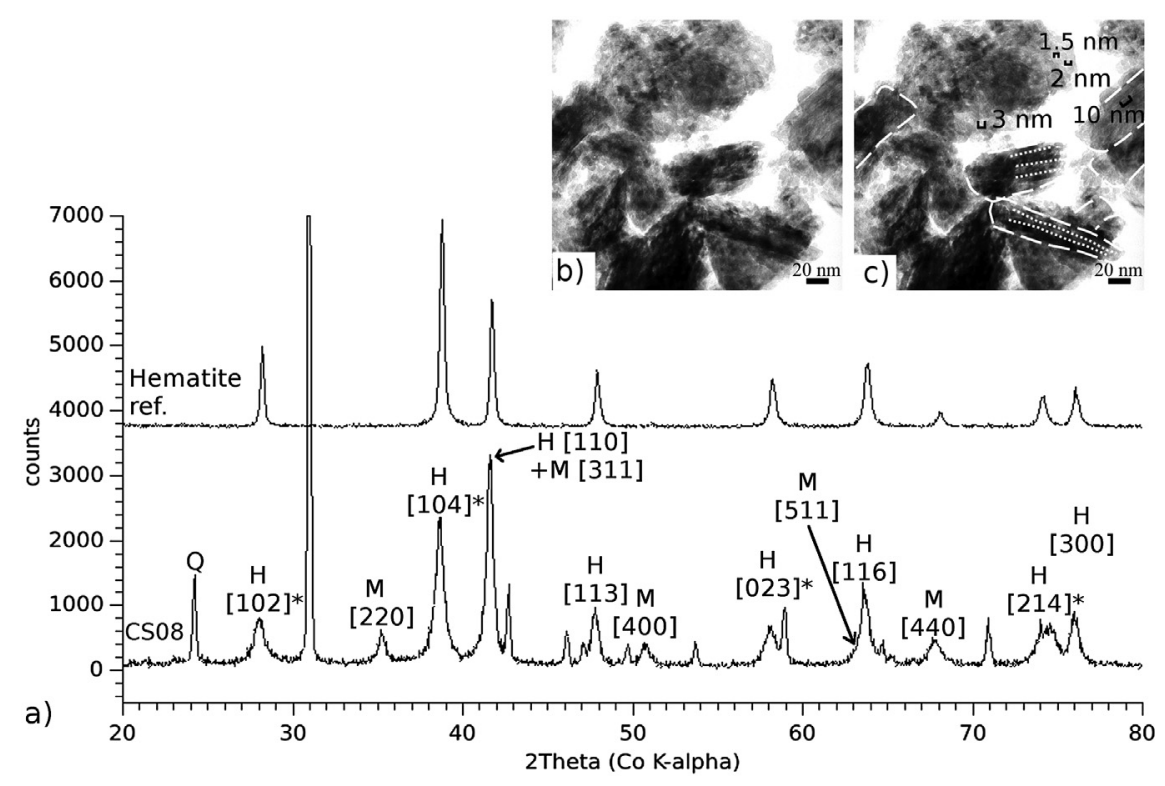

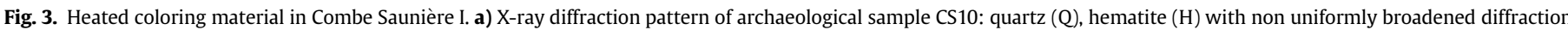

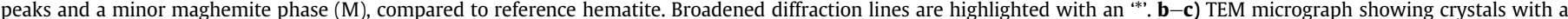

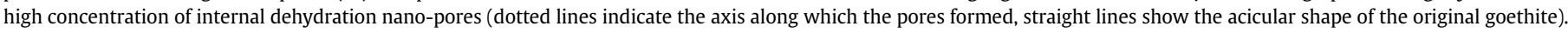

We focus here on class A, which consists of more than 500 pieces (i.e. half of the collection) recovered from 3 square meters. Within this area there were two concentrations of class A material, each yielding more than 200 sharp fragments smaller than $1 \mathrm{~cm}$. In square M14, six class A raw blocks were found between the two main concentrations of fragments. Therefore, the spatial organization and the large amount of little sharp pieces are indicative of activity areas used for crushing and grinding of coloring material (Fig. 4). The XRD study of class A samples shows that the red materials are composed exclusively of a mixture of hematite and approximately 5\% quartz. Furthermore, it was possible to distinguish the specific characteristics of a heated goethite.

Our second sampling was aimed at testing the possibility of distinguishing intentional versus unintentional heating of goethite. Nine of the largest blocks, all exceeding $5 \mathrm{~cm}$, were selected and sampled at internal and external points. All X-ray diffraction patterns corresponding to the twenty samples show a pure hematite phase with diffraction lines not uniformly broadened (Fig. 5a), indicating the possible use of heat treatment. Further examination and analysis by TEM ( 5 samples, i.e. 2 internal and 3 external) shows dehydration nano-pores of less than $5 \mathrm{~nm}$ diameter (Fig. 5b). These are oriented along the longitudinal crystallographic direction of the hematite crystals that retained the shape of the acicular precursor goethite crystals (Fig. $5 \mathrm{c}$ and d). Original blocks of goethite pigment must have undergone significant penetrative heat treatment, that resulted in their complete transformation to hematite. We summarize the results in Table 6. We can infer that the temperature used was high enough and the duration long enough to complete the phase of transformation homogeneously into the core of the biggest objects. Using the results of Pomiès et al. (1999c) who studied the pore size as a function of temperature in a synthetic goethite, we can estimate, from the very small pore size (less than $5 \mathrm{~nm}$ ), that the temperature used was probably in the range of $300-400^{\circ} \mathrm{C}$, and that the heating lasted at least $2 \mathrm{~h}$ to induce a fully uniform transformation of all crystallites.

According to the spatial distribution of the remains at the campsite, the concentrations of red coloring materials of heated class A pieces were at the edge of a large pile of flint and is not associated with any burned artifact or a fireplace. Therefore, it is likely that the heated class A materials, organised in such a 
Table 4

Les Maîtreaux: list of laboratory labels attributed to analyzed artifacts according to petrological class, with indication of square meter.

\begin{tabular}{lll}
\hline Les Maîtreaux & Square & Class \\
\hline MA01 & N14C & $\mathrm{A}$ \\
MA02 & M14B & $\mathrm{A}$ \\
MA03 & N14D & $\mathrm{A}$ \\
MA04 & M13A & $\mathrm{A}$ \\
MA05 & M13B & $\mathrm{A}$ \\
MA06 & M14C & $\mathrm{A}$ \\
MA07 & M14C & $\mathrm{A}$ \\
MA08 & M14D & $\mathrm{A}$ \\
MA09 & M14D & $\mathrm{A}$ \\
MA10 & M14D & $\mathrm{A}$ \\
MA11 & N19A & $\mathrm{B}$ \\
MA12 & O20C & $\mathrm{B}$ \\
MA13 & N19B & $\mathrm{C}$ \\
MA14 & O20D & $\mathrm{C}$ \\
MA15 & N11A & $\mathrm{D}$ \\
MA16 & M16D & $\mathrm{D}$ \\
MA17 & M17B & $\mathrm{D}$ \\
MA18 & M19A & $\mathrm{D}$ \\
MA19 & O9D & $\mathrm{E}$ \\
MA20 & K15C & $\mathrm{E}$ \\
MA21 & M17C & $\mathrm{E}$ \\
MA22 & N18D & $\mathrm{E}$ \\
MA23 & N19C & $\mathrm{E}$ \\
MA24 & N21A & $\mathrm{E}$ \\
\hline
\end{tabular}

restricted area, do not result from an accidental heating following their deposition (cf. Wadley, 2009).

Moreover, after ethnographical records (Inizan et al., 1999), experiments (Crabtree and Butler, 1964) and studies of heat-treated siliceous flaked artifacts (Schmidt et al., 2012; Aubry et al., 2003; Kuzmin and Orlova, 1998; Tiffagom, 1998), the Solutreans are known to have used heat-treatment of flint to enhance the knappability, and thus facilitate the Laurel Leaf shaping and retouch of tools using pressure-flaking. In order to prevent flint exploding in fireplaces, Solutreans would most likely have heated flint in ground ovens to homogenize the heat to ensure gradual rise and fall of temperature. We can assume that a similar heating strategy was applied to class A materials, since there is good evidence that they were not directly exposed to burning organic material, but were heated for a relatively long time at well-controlled temperatures between 300 and $400{ }^{\circ} \mathrm{C}$. This combination of evidence (the spatial distribution of class A sharp fragments and raw blocks as well as the intentional, homogeneous heating of all of the artifacts in the area) allow us to conclude that the flint flaking workshop in Les Maîtreaux also included a workshop for the preparation of red powder.

The practice of intentional heating of yellow material points to a good knowledge of fire and fireplaces by Solutreans. It also demonstrates a thorough knowledge of the properties of the coloring materials. It is, to date, the first strong archaeological evidence that confirms the hypothesis that controlled heating of coloring materials was used for the production of a specific red coloring material. Our results also show that flint workshops were places of diverse activities of production, probably conducted by different members of the group who had complementary tasks.

Since the heat-produced hematite is a near pure product, we support the hypothesis that the aim of heating was to produce a particular well-characterized material with controlled and known properties, namely pure hematite. This is a mineral with powerful coloring, drying and abrasive properties (Christensen, 1996; White, 1996; Philibert, 1994). Moreover, as the Solutreans had at their disposal other red materials that they brought to the site in their natural state (hematite-rich clay, ferruginous sandstone, goethite-

Table 5

Les Maîtreaux: Assemblage sampling and analysis according to petrological class.

\begin{tabular}{|c|c|c|c|c|c|}
\hline $\mathrm{Nb}$ of objects & $\begin{array}{l}\text { Hematite } \\
\text { (A) }\end{array}$ & Goethite (B) & Hematite-rich sandstone $(C)$ & Goethite- and hematite-rich standstone (D) & Hematite-rich clay (E) \\
\hline 1021 & 501 & 46 & 51 & 186 & 237 \\
\hline 24 (34 samples) & 20 (10 blocks $>5 \mathrm{~cm}$ in length) & 2 & 2 & 4 & 6 \\
\hline 1 & MA1e-MA10e and MA1i-MA10e- & MA11 and MA12 & MA13 and MA14 & MA15-MA18 & MA19-MA24 \\
\hline 6 (8 samples) & 5 & 1 & & & 2 \\
\hline 1 & MA1e-M3e and MA1i-MA2i & MA12 & & & MA19 and MA 21 \\
\hline
\end{tabular}

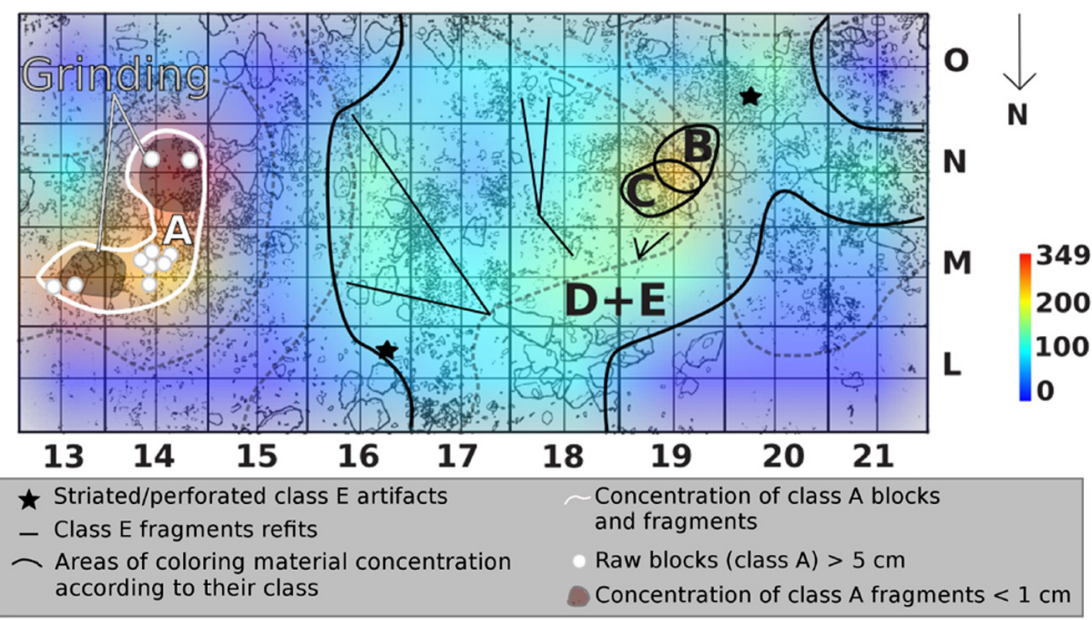

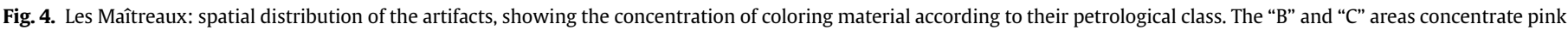

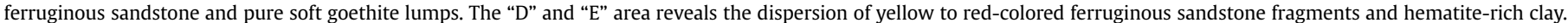
The location with class A material shows two concentrations of sharp fragments and 10 raw blocks in the same restricted area. 


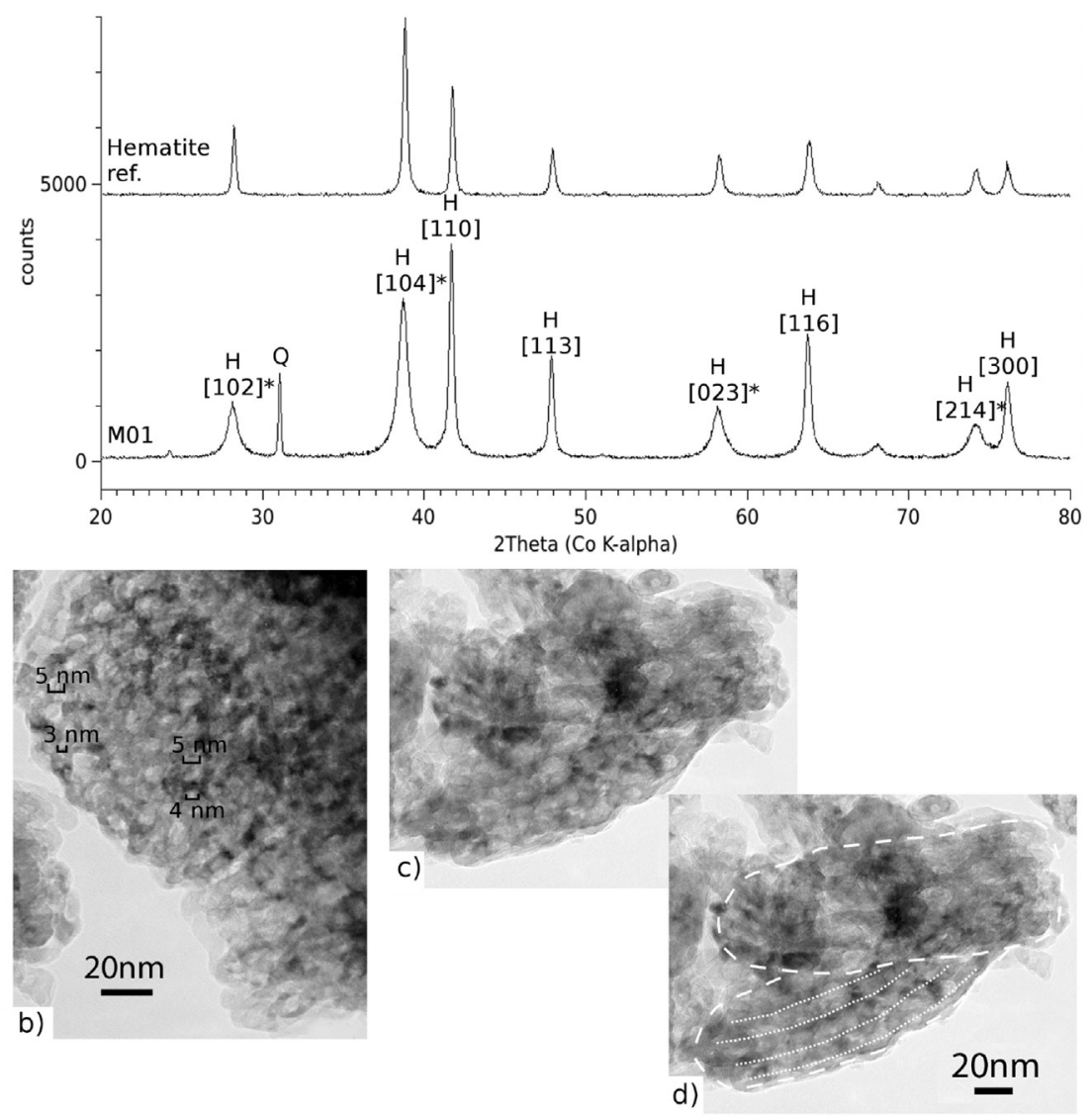

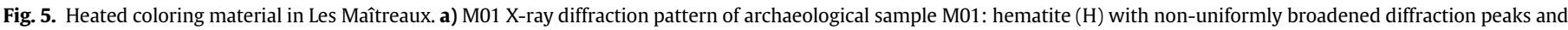

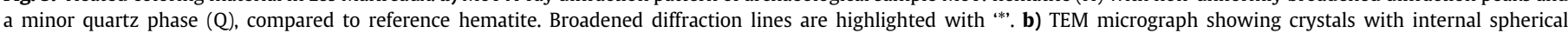

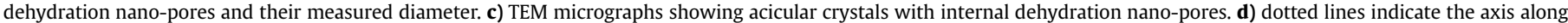
which the pores formed, straight lines show the acicular shape of the original goethite.

hematite-rich sandstone), and since quartz is rough, it is most likely that, the desired raw material had to be poor in quartz. It was not only designed to be a coloring material but possibly an abrasive for the bone and antler industry as well.

\subsection{The Grotte Blanchard in La Garenne}

Five black, four yellow and seven red pigment fragments (Fig. 6a; Table 7) were observed and analyzed. The elemental composition was determined by PIXE using the C2RMF facility and the mineralogical structure determined by $\mu$-X-ray diffraction (Lahlil et al., 2014). Red pigments are, overall, relatively pure and are made of hematite. Yellow pigments contain goethite with quartz and hydrated manganese oxide impurities. X-ray diffraction shows two types of red pigments. One block has narrow diffraction lines characteristic of the natural origin of the pigment, while the remaining 4 red blocks have diffraction lines that are broadened, with an inversion of intensity of the [104] and [110] lines (Fig. 6b).

TEM-FEG was used in the IMPMC laboratory to identify the use of heating. We selected a red material with narrow X-ray diffraction peaks (SM16) as a reference for natural material and four samples with broadened diffraction peaks (SM03, SM11, SM20, SM22) to check if the characteristics observed were due to the small size or preferred orientation of crystals, rather than heat-treatment of an original goethite. For comparison we also studied the only black sample (SM04). XRD analysis showed this to be goethite, not manganese oxide. The results are summarized in Table 8 .

\subsubsection{Black goethite}

This goethite presents traces of manganese oxide identified by EDX. At low magnification, the mineral shows a compact and botryoidal structure (Fig. 7a) with a cross-section that has a radial stratified structure made of longitudinal crystals oriented along the diameter (Fig. 7b). The internal structure is less compact and needle-like crystals of several microns long are completely disordered or assembled into "bundles" (Fig. 7c). When crushed for TEM observations, the resulting powder is yellow. Electron diffraction allowed the identification of single acicular goethite crystals, very thin, $300-500 \mathrm{~nm}$ long and $50 \mathrm{~nm}$ wide without nano-pores or signs of dehydration (Fig. 7d).

\subsubsection{Natural hematite}

SM16 is a red lump of material which has sets of parallel grooves on its surface indicative of anthropogenic modification. The X-ray diffractogram is free of anomalies, i.e. without broadening or inversed height of the [104] and [110] peaks. The large sheets observed in SEM-FEG (Fig. 8a, b \& c) have been destroyed by grinding in an agate mortar, for grid preparation and TEM examination. Electron micro-diffraction is characterized by continuous thin concentric rings; some $d_{h k l}$ rings are missing indicative of a polycrystalline structure with sub-nano grains preferentially oriented (Fig. 8d).

\subsubsection{Hematite with an anomalous X-ray diffractogram}

First case. The morphology observed by SEM-FEG is different for each sample. SM03 is a star-like multi-domainic, twinned goethite 
Table 6

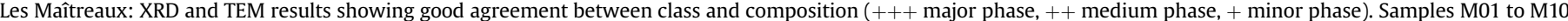

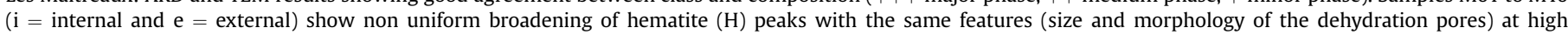
magnification with TEM. Goethite $(G)$ shows fine acicular crystals.

\begin{tabular}{|c|c|c|c|c|c|c|c|}
\hline \multirow[t]{2}{*}{ Les Maîtreaux } & \multicolumn{3}{|l|}{ XRD } & \multicolumn{4}{|c|}{ TEM } \\
\hline & Hematite & Goethite & Quartz & Non uniform broadening & H Crystal morphology & Pores & G cyrstal morphology \\
\hline MA1-MA10 (i and e) & +++ & & + & Yes & Pseudo acicular & Spherical 2-5 nm & \\
\hline MA11 & & +++ & + & & & & \\
\hline MA12 & & +++ & + & & & & Acicular \\
\hline MA13-MA14 & + & & +++ & & & & \\
\hline MA15-MA18 & + & + & +++ & & & & \\
\hline MA19 and MA21 & +++ & ++ & + & & Massive crystals & & Acicular \\
\hline MA20 and MA22-24 & +++ & ++ & + & & & & \\
\hline
\end{tabular}

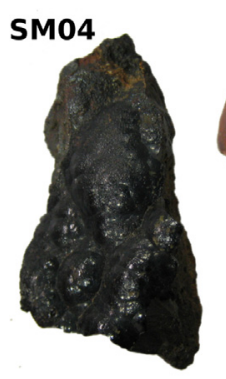

\section{SM16}

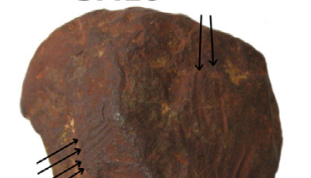

SM22

SM03
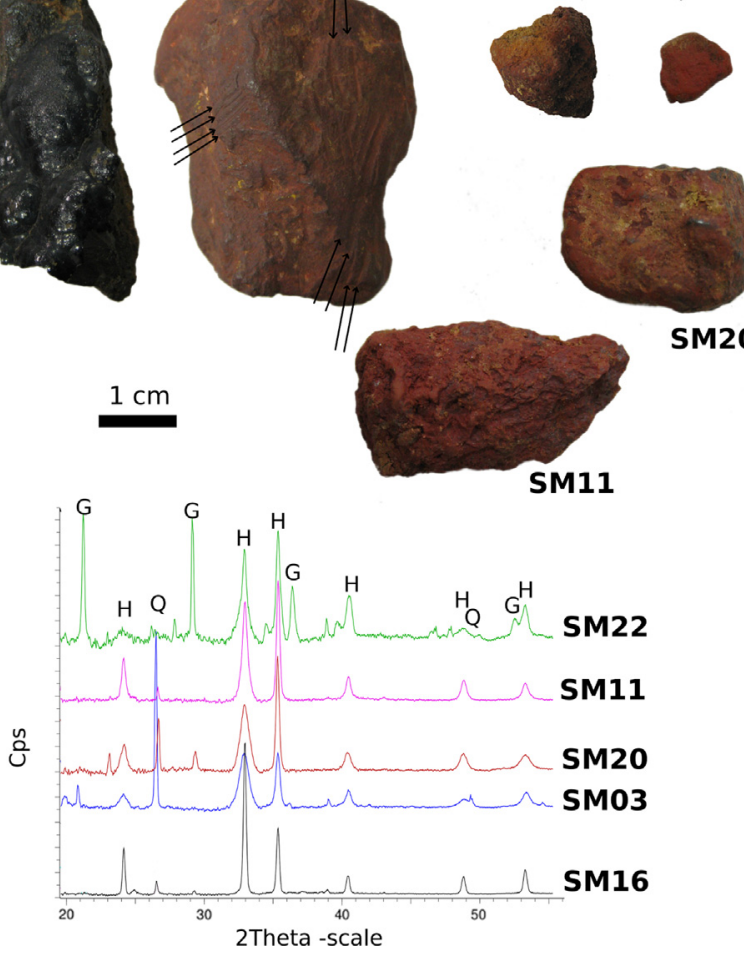

Fig. 6. Blanchard-La Garenne a) Ferruginous lumps; arrows point to the use traces (groups of parallel striations); b) X-ray diffraction pattern of five red analyzed pigments. $\mathrm{H}=$ hematite, $\mathrm{G}=$ goethite and $\mathrm{Q}=$ quartz; the four samples SM03, SM11, SM20 and SM22 have wider diffraction peaks with an inversion of intensity of the [104] and [110] lines compared with SM16 narrow diffraction lines. SM22 contents hematite and a minor goethite phase.

(Fig. 9a). SM22 is a multi-domainic goethite crystal with parallel subunits referred to as domains or intergrowths (Fig. 9c). Both goethite morphologies may arise from the alkaline nature of the growth media. These samples contain also hematite crystals, that give the red color to the blocks. These coexist with goethite crystals. The hematite, identified by electron $\mu$-diffraction, has an acicular morphology characteristic of goethite with internal dehydration nano-pores. This morphology is characteristic of heated precursor goethite crystals and is transformed at relatively low temperatures (Pomiès et al., 1999c). The nano-pores are spherical (Fig. 9b) for SM03 or longitudinal along the [001] axis of the precursor crystal (Fig. 9d) for SM22. The residual goethite is due to incomplete transformation

Second case. SM11 and SM20 samples have hematite crystals that do not contain pores. The SEM- FEG micrographs show diagnostic morphologies. The crystals in the SM11 sample are elongated and thick with a parallelepiped form and faceted extremities (length 2 to 3 times the thickness), or occur as hexagonal "pellets" (Fig. 10a) indicative of a prolonged heating temperature of at least $650{ }^{\circ} \mathrm{C}$ (Pomiès, 1997). The TEM examination of these crystals shows some crystals still transparent to the electron beam. They are elongated with developed thickness and have rounded or quasihexagonal shaped extremities (Fig. 10b). Some of them have coalesced, indicating an advanced goethite-hematite transformation as a result of heating over $650{ }^{\circ} \mathrm{C}$. Crystals grew in three directions and dehydration is complete. Notably, the good agreement between the SEM-FEG and TEM-FEG results excludes the interpretation of TEM observations as isolated cases.

With low magnification SEM-FEG, the structure of SM20 sample is interpreted as needles with $0.3-0.5 \mu \mathrm{m}$ length. At higher magnification a pile of platelets with sections estimated to 15-17 nm thick, sometimes with a clearly hexagonal shape (Fig. 10c) can be discerned. Fig. 10d (TEM-FEG) shows both pseudo acicular and hexagonal morphologies, identified by electron microdiffraction as hematite. Three single crystals have coalesced to form one polycrystal with grain boundaries. The transformation goethite-hematite is no more topotactic than the SM03 and SM22 cases. Atom migration has enabled recrystallization tending towards an hexagonal morphology characteristic of the hematite structure. Acicular crystals reflect the shape of the precursor goethite crystals. When compared with synthesized goethite that has been experimentally heated (Pomiès et al., 1999c), we estimate

Table 7

La Garenne: list of laboratory labels attributed to analyzed artifacts and corresponding analysis conducted.

\begin{tabular}{|c|c|c|c|}
\hline La Garenne & Corpus & Red & Black \\
\hline Macro- and mesoscopic Observation & 16 (4 yellow) & 7 & 5 \\
\hline textmuXRD- & 6 & 5 & 1 (black goethite) \\
\hline Sample label & & SM03, SM11, SM16, SM20, SM22 & SM04 \\
\hline SEM-FEG & 6 & 5 & 1 \\
\hline Sample label & & SM03, SM11, SM16, SM20, SM22 & SM04 \\
\hline TEM-FEG & 5 & 5 & \\
\hline Sample label & & SM03, SM11, SM16, SM20, SM22 & SM04 \\
\hline
\end{tabular}


Table 8

La Garenne: textmuXRD, SEM-FEG and TEM-FEG results with description of the hematite (H) and goethite (G) morphology.

\begin{tabular}{|c|c|c|c|c|c|c|c|c|}
\hline \multirow[t]{2}{*}{ La Garenne } & \multicolumn{4}{|l|}{$\mu \mathrm{XRD}$} & \multirow[t]{2}{*}{ SEM-FEG } & \multicolumn{3}{|l|}{ TEM-FEG } \\
\hline & Hematite & Goethite & Quartz & Non uniform broadening & & H crystal morphology & Heating features & G crystal morphology \\
\hline $\begin{array}{l}\text { SM03 } \\
\text { SM04 }\end{array}$ & +++ & + & +++ & Yes & $\begin{array}{l}\text { Star-like structure } \\
\text { Botryoidal structure }\end{array}$ & Acicular & Spherical nano-pores & Acicular \\
\hline SM11 & +++ & & + & Yes & Hexagonal pellets & Quasi-hexagonal & Recrystallization in 3D & \\
\hline SM16 & +++ & & & & Sheets of hematite & Polycrystaline nano-crystals & & \\
\hline SM20 & +++ & & ++ & & Platelets (hexagonal) & Quasi-hexagonal and acicular & Recrystallization in 3D & \\
\hline SM22 & +++ & & ++ & Yes & Parallel sub-units & Acicular & Longitudinal nano-pores & Acicular \\
\hline
\end{tabular}
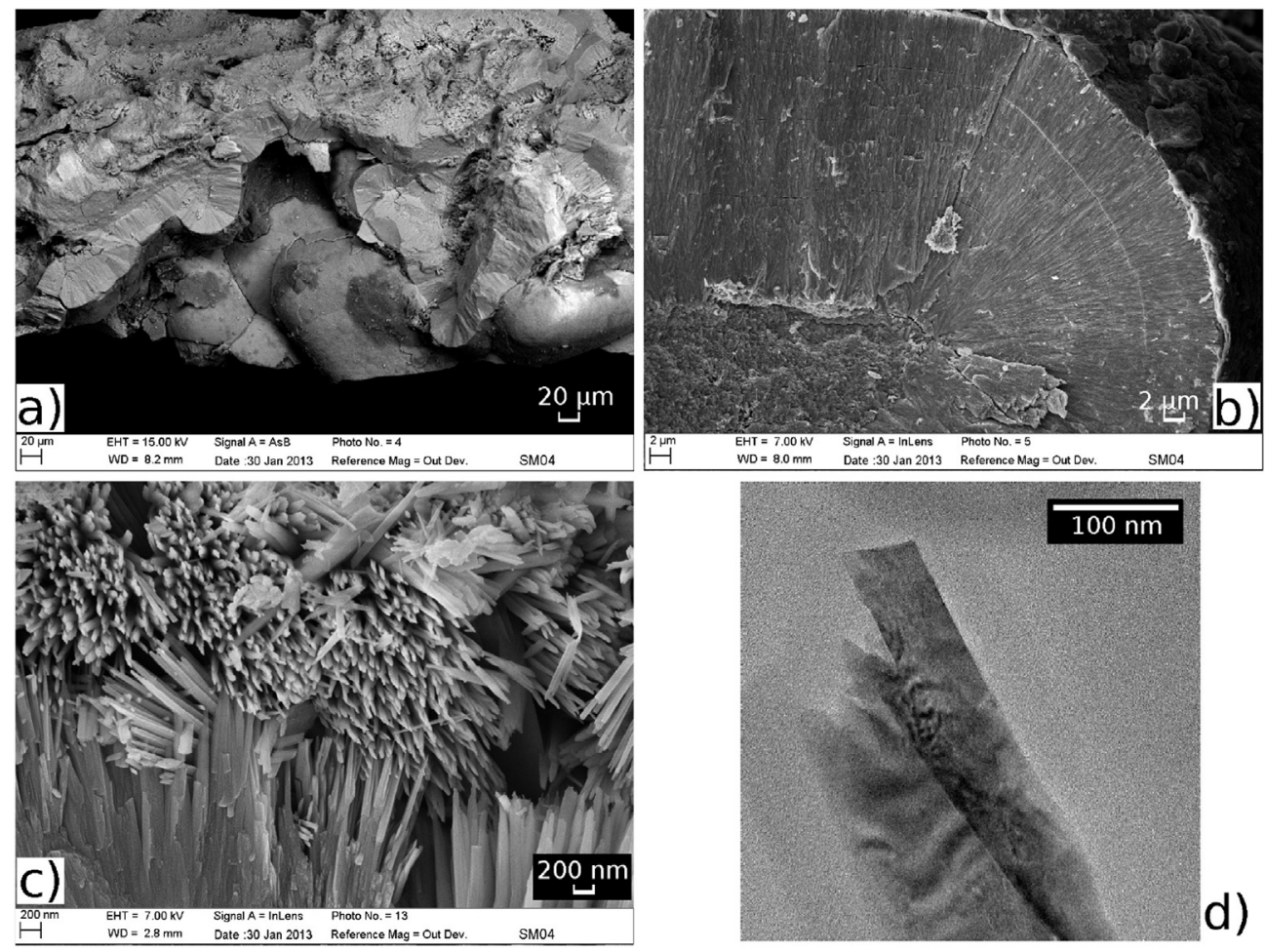

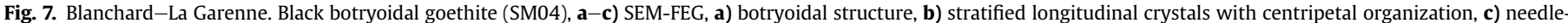
like goethite crystals, d) TEM-FEG showing thin acicular crystal of goethite.

that the transformation from goethite occurred at temperatures between 650 and $800{ }^{\circ} \mathrm{C}$.

For SM11 and SM20 samples, the thermal history of the hematite-rich fragments recorded by the crystals documents a high temperature of heating that was continuously maintained by probable ventilation and/or fuel addition. Since there are no finds with original rock surfaces, we cannot determine if there was ever contact with organic fuel. It is possible that fire pits or ovens were used.

In sum, although the corpus is quite small, we observed three types of goethite: acicular needle, multi-domainic and domainic star-like which could indicate three different kinds of raw goethiterich material. The morphology of crystals is dependent of thermodynamic conditions during crystalization (rock formation and weathering). Here, the occurrence of three different morphologies may indicate probable three different geological origins. Only subhexagonal or hexagonal hematite crystals with well-developed thickness (in contrast to natural hematite) are characteristic of heated goethite at temperatures up to $650{ }^{\circ} \mathrm{C}$. During heating, the goethite crystals retain their original morphology until temperatures are high enough to start the recrystallization. In this latest situation, the morphology of the precursor goethite crystals is lost.
For hematite, we noted that in some cases such as (SM11), the SEMFEG and TEM-FEG correlated examination identified the recrystallization and the progress of the transformation. The SM11 hematite, well-crystallized from heating, is very different from the poorly crystallized natural hematite found at this site or other studied sites.

\section{Conclusion}

This study, which incorporated spatial analysis of the archaeological remains, geological contexts surrounding archaeological sites, and physico-chemical analyses using XRD and $\mu$ XRD, SEM and SEM-FEG as well as TEM and TEM-FEG, enabled us to differentiate between intentional and accidental heating of coloring materials at the Les Maîtreaux, Combe Saunière I and La Garenne archaeological sites. It confirms the use of planned and well-controlled intentional heating to produce red hematite from goethite in the Solutrean and Magdalenian Periods. The three different archaeological contexts a hunting camp-site (Combe Saunière I), a rock art site (La Garenne) and a production camp-site with at least two main activities, i.e. flint flaking and coloring material processing - reveal divers aspects of the industry of the coloring materials as well as the skills 

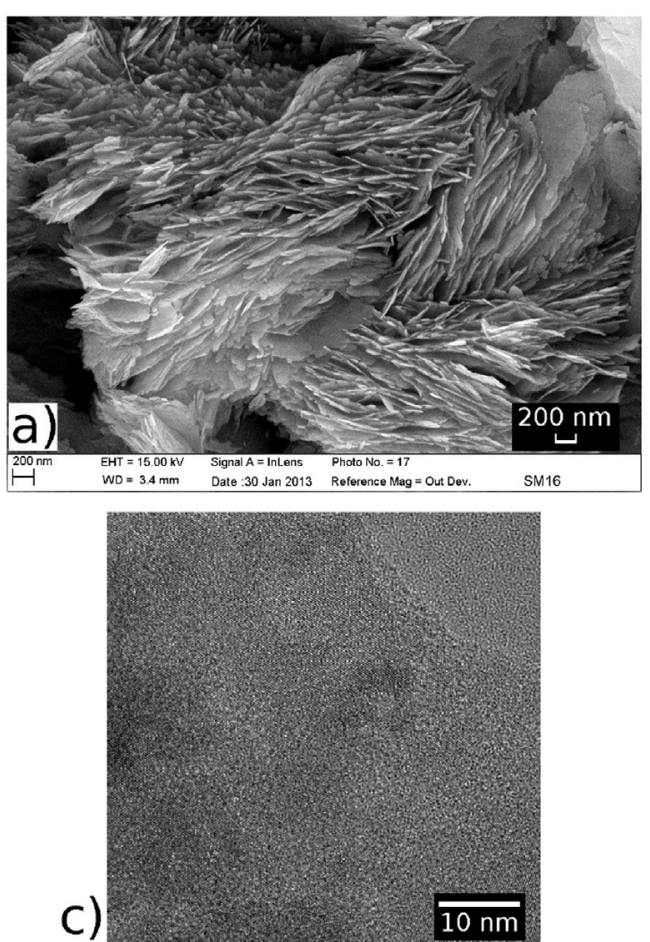
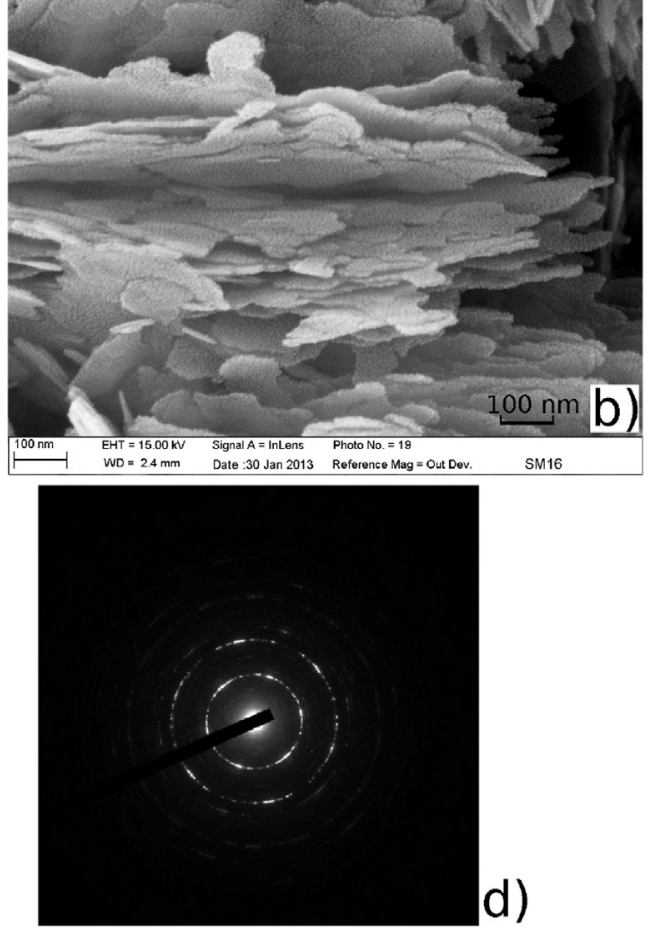

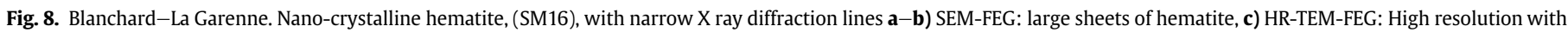
lattice fringes, imaging lattice spacings, $\mathbf{d}$ ) electron diffraction pattern showing the polycrystalline $\mathrm{d}_{\mathrm{hkl}}$ rings.
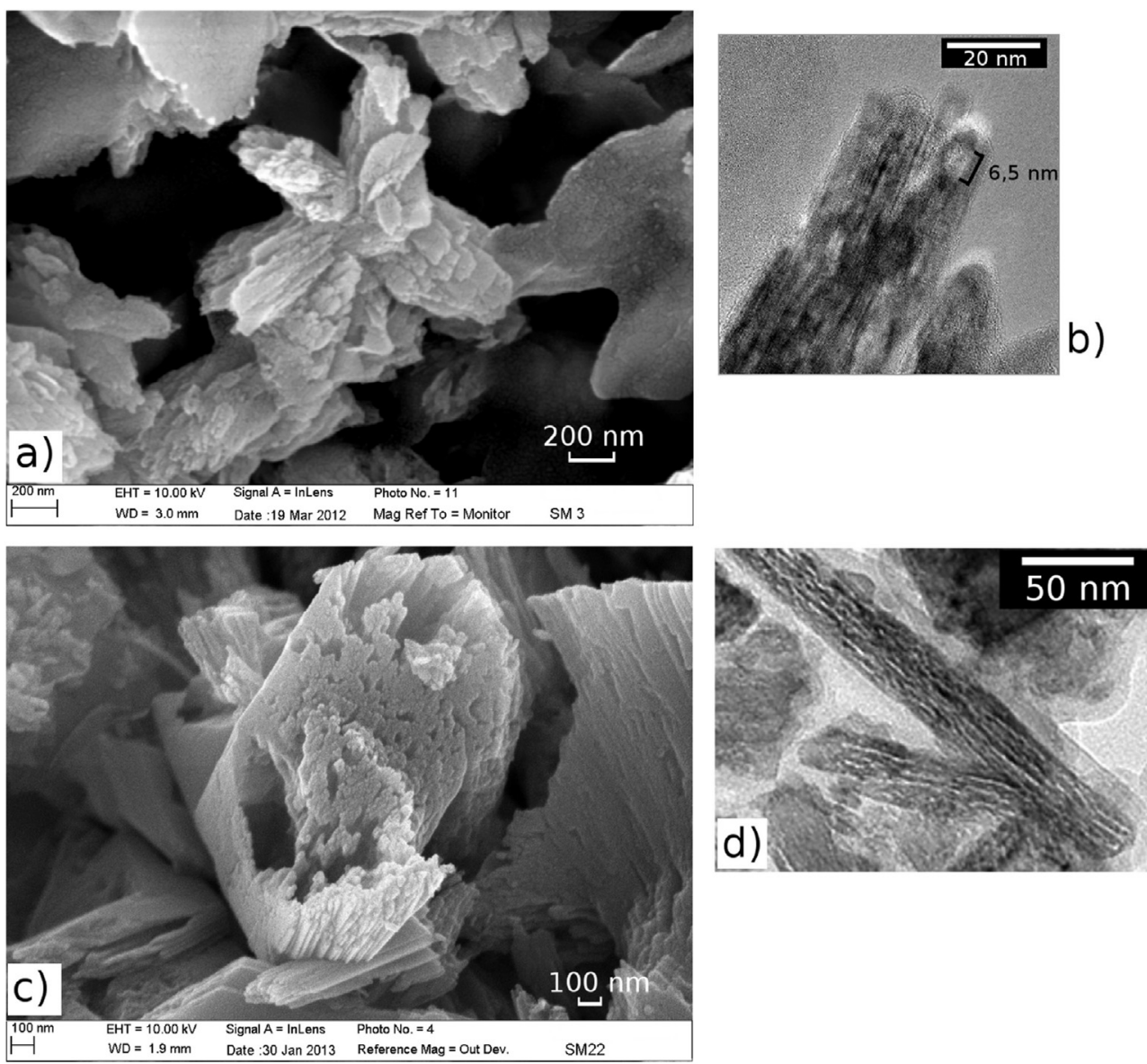

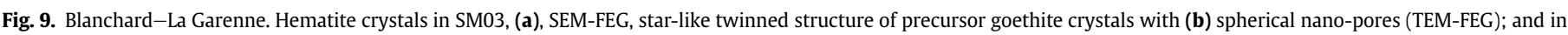
SM22, (c) SEM-FEG, multi-domainic structure of precursor goethite crystals with (d) longitudinal nano-pores (TEM-FEG). 

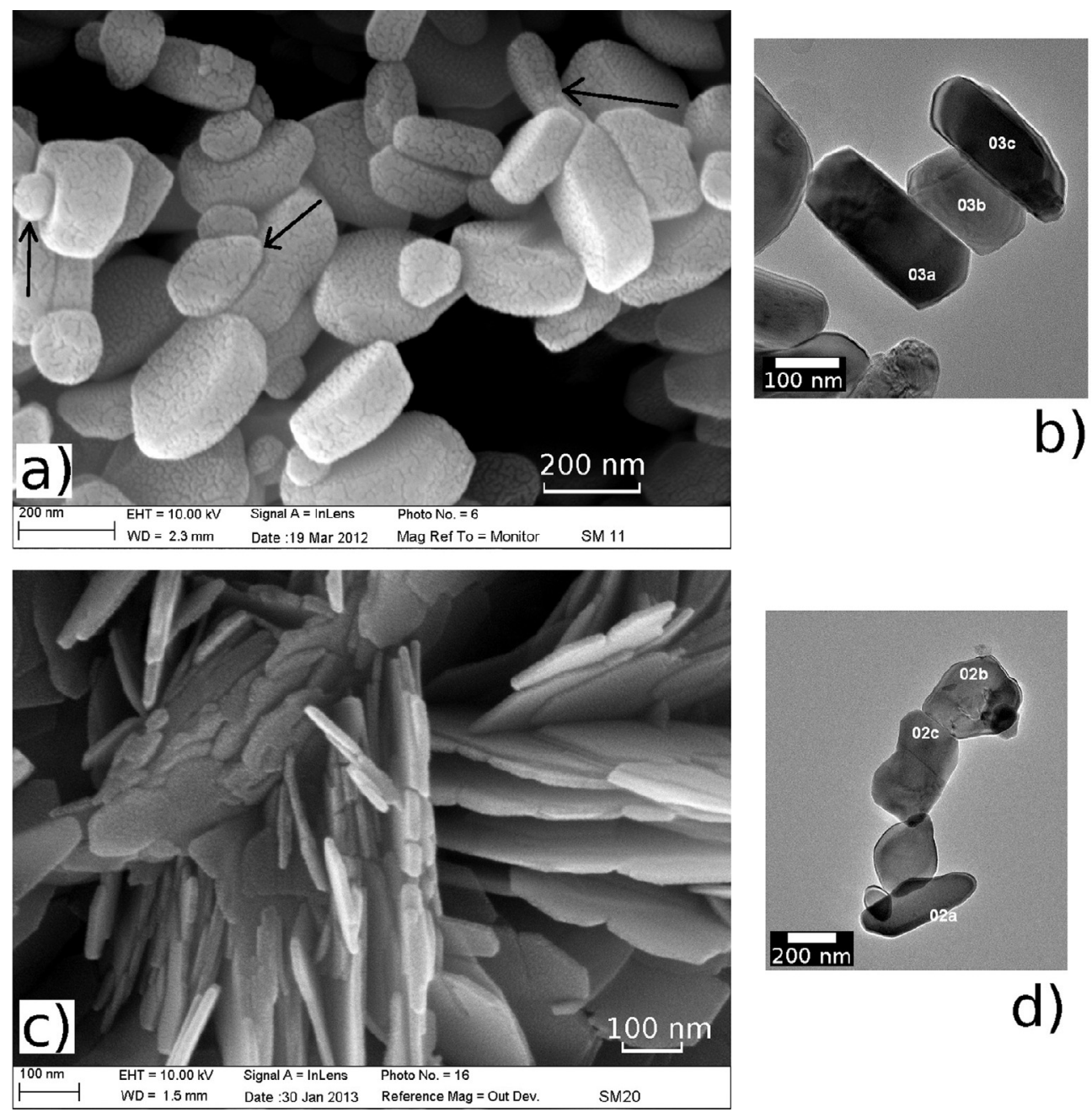

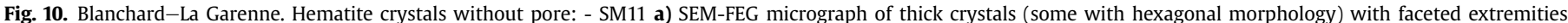

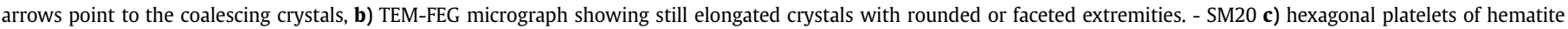
(SEM-FEG) more often exposing their cross-section, d) TEM-FEG micrograph showing acicular (02a), pseudo-hexagonal hematite (02b), and coalescing crystals (02c).

developed to manage the thermal transformation of the raw materials.

Whilst archaeological records yield considerable amount of red pigment pieces, only a few types of materials were heated, certainly to change their hue and physico-chemical properties. Most of the red pigments occurred naturally and could be collected from surrounding environments. Thermal transformation was reserved for specific yellow raw materials and likely used to obtain a product with powerful drying or abrasive properties as well as for the color and coloring power of the new synthesized red material.

The transformation of goethite to hematite by heating, in the open-air Laurel Leaf workshop at Les Maîtreaux camp site is of great importance. The spatial distribution of the technical activities with evidence for a pigment workshop which must have involved heating processes and red powder production is unique in the Paleolithic record. The time and temperature appear to have been carefully controlled, and we can reasonably propose that the Solutreans in Les Maîtreaux placed the lumps of goethite in an oven under the hearth, so that the rocks were homogeneously heattransformed but protected from the fuel (charcoal, fatty products, etc.). It is proposed that this was likely to have been the same technical procedure used to improve the flint qualities for the shaping of Laurel Leaves. In contrast, given the evidence for irregular heating and mixing with organic matter, the Solutrean rock-shelter Combe Saunière I had archaeological remains that seem more likely to have been accidentally heated.

The Magdalenian example is related to rock art. The pigments found in the cave were probably used for the art, since pieces of red iron oxide-rich material have traces of use such as grooves or striations. Four fragments of red pigment on five studied have been heated. Two of them show incomplete heating under low temperature, but the general color of the blocks is red. This indicates expedient or accidental heating. Two others have significant recrystallization indicative of relatively high temperature treatment above $650{ }^{\circ} \mathrm{C}$. This is comparable to the apparent high temperature used for goethite thermal transformation (up to $800{ }^{\circ} \mathrm{C}$ ) mentioned in the Epipaleolithic of the Riparo Dalmeri in Italy (Gialanella et al., 2011). Our results highlight new technical aspects of the Magdalenian culture on the La Garenne site (Lahlil et al., 2014) indicative of continuous management of fireplace temperatures of sufficient duration to accomplish the structural internal transformation. This may have required specific procedures or equipment to ensure adequate ventilation to reach and maintain heat levels. The relationship with the rock painting still needs to be established by further investigations and the search for thermally treated pigment could yield new evidence for associations between 
pigments on the walls with those found in the archaeological horizons.

Coloring materials are rocks with good potential to record the history of heating techniques by providing clues for invention of ingenious techniques to fundamentally transform intrinsic qualities of the materials. Even if heating yellow goethite to make hematite did not require much care, Les Maîtreaux and La Garenne archaeological records give strong evidence of sophisticated procedures to heat-transform goethite-rich rocks. Further field research may determine the specific heating structures used as deduced from heated flint and pigment in the Solutrean contexts. Focus on experimental heating procedures could enrich our knowledge of fireplace function and the effects of various parameters on the final synthesized material, such as temperature rise and decrease, type of organic material, position in relation to heat, mixing with other materials.

\section{Acknowledgements}

It is a pleasure to thank Thierry Aubry, Jean-Pierre Chadelle, Jean-Michel Geneste, Patrick Paillet and Bertrand Walter, who gave us access to the artifacts as well as the archaeological documentation. We are indebted to Michel Menu, Martine Regert and MariePierre Pomiès for having directed the study of Les Maîtreaux and Combe Saunière during $\mathrm{H}$. Salomon Master thesis and $\mathrm{PhD}$ in C2RMF. Françoise Pillier and Stephan Borensztajn are gratefully acknowledged for their help in electron microscopy observation, respectively by TEM and SEM-FEG (at Interfaces and Electrochemical Systems Laboratory - LISE, CNRS-Paris VI). We warmly thank Jean-Claude Dran and Carol Lentfer for their thorough and critical reading. Funding for this study was provided by the ANR MADAPCA (CNRS, France), the F.R.S.-FNRS ( ${ }^{\circ}$ PaCoMa 11191) (Belgium) and the University of Liège ( $\left.n^{\circ} 2009 / 2526\right)$. The authors thank the four anonymous reviewers for their constructive comments and suggestions.

\section{References}

Allain, J., 1957. Nouvelles découvertes dans le gisement magdalénien de la Garenne commune de Saint Marcel, Indre. Note préliminaire. Bull. la Soc. Préhist. Fr. 54 (3-4), 223-227.

Allain, J., Desbrosse, R., Kozlowski, J., Rigaud, A., Jeannet, M., Leroi-Gourhan, A., 1985. Fascicule 1: le Magdalénien à navettes. Gall. Préhist. 38, 37-124.

Aubry, T., Walter, B., Robin, E., Plisson, H., Benhabdelhadi, M., 1998. Le site solutréen de plein air des Maîtreaux (Bossay-sur-Claise, Indre-et-Loire): un faciès origina de production lithique. Paléo 10, 163-184.

Aubry, T., Walter, B., Almeida, M., Neves, M., 2003. Solutrean Laurel leaf production and raw material procurement during L.G.M. in southern Europe: two exemples form Central France and Portugal. In: Soressi, M., Dibble, H.L. (Eds.), Multiple Approaches to Bifaces Variability. University of Pennsylvania, Museum of Archaeology and Anthropology, Pennsylvania, pp. 165-182.

Aubry, T., Walter, B., Almeida, M., Liard, M., Neves, M., 2004. Approche fonctionnelle des sites dit d'atelier : l'exemple des occupations solutréennes et badegouliennes des Maîtreaux (Indre-et-Loire, France). In: Bodu, P., Constantin, C. (Eds.) Approche fonctionnelle en Préhistoire, XXVème Congrès Préhistorique de France. 24-26 novembre 2000. Nanterre: Éditions du CNRS, pp. 249-264.

Audouin, F., Plisson, H., 1982. Les ocres et leurs témoins au Paléolithique en France enquête sur leur validité archéologique. Cah. Cent. Rech. Préhist. 8, 33-80.

Baffier, D., Girard, M., Menu, M., Vignaud, C., 1999. La couleur à la Grande Grotte d'Arcy-sur-Cure (Yonne). L'Anthropologie 103 (1), 1-21.

Cabrera-Garrido, J.M., 1978. Les matériaux des peintures de la grotte d'Altamira. In: Actes de la $5^{\text {eme }}$ réunion internationale de l'ICOM, pp. 1-9. Zagreb.

Castel, J., Liolios, D., Chadelle, J.-P., Geneste, J.-M., 1998. De l'alimentaire et du technique : la consommation du renne dans le Solutréen de la grotte de Combe Saunière. In: Brugal, J.-P., Meignen, L., Patou-Mathis, M. (Eds.), Économie préhistorique: les comportements de subsistance au Paléolithique, Actes des rencontres des XVIIIème rencontres internationales d'archéologie et d'Histoire d'Antibes, 23-25 octobre 1997, Sofia-Antipolis, APDCA, pp. 433-450.

Chadelle, J.-P., Geneste, J.-M., Plisson, H., 1991. Processus fonctionnels de formation des assemblages technologiques dans les sites du Paléolithique supérieur. Les pointes de projectiles lithiques du Solutréen de la grotte de Combe-Saunière (Dordogne, France), 25 ans d'études technologiques en préhistoire: bilan et perspectives. In: Rencontres internationales d'archéologie et d'histoire d'Antibes, pp. 275-287.

Chalmin, E., Menu, M., Pomiès, M.-P., Vignaud, C., Aujoulat, N., Geneste, J.-M., 2004. Les blasons de Lascaux. L'Anthropologie 108, 571-592.

Chalmin, E., Vignaud, C., Salomon, H., Farges, F., Susini, A., Menu, M., 2006. Minerals discovered in palaeolithic black pigments by transmission electron microscopy and micro-X-ray absorption near-edge structure. Appl. Phys. A Mat. Sci. Process. 83 (2), 213-218.

Christensen, M., 1996. Un exemple du travail de l'ivoire du Paléolithique allemand : apport de l'étude fonctionne des outils aurignaciens de Geissenklöstrele. Technè 3, 39-54.

Cornell, R., Schwertmann, U., 1996. The Iron Oxides: Structure, Properties, Reactions, Occurrence and Uses. VCH, Weinheim.

Couraud, C., 1987. Les matières pigmentées utilisées en préhistoire : provenance, préparation, mode d'utilisation. PACT 17, 377-391.

Crabtree, B., Butler, B.R., 1964. Notes on experiments in flint knapping: heat treatment of silica minerals. Tebiwa 7, 1-6.

de Viguerie, L., Beck, L., Salomon, J., Pichon, L., Walter, P., 2009. Composition of renaissance paint layers. Simultaneous PIXE and backscattering spectrometry. Anal. Chem. 81 (19), 7960-7966.

Despriee, J., Rigaud, A., Vialou, D., Gageonnet, R., 2001. Bulletin de l'association pour la sauvegarde du site archéologique d'argentomagnus et amis du musée - le coteau de la garenne. Collaborative research project 1999-2001.

Ducasse, S., 2012. What is left of the Badegoulian "interlude"? New data on cultural evolution in southern France between 23,500 and 20,500 cal. BP. Quat. Int. 272-273, 150-165.

d'Errico, F., Salomon, H., Vignaud, C., Stringer, C., 2010. Pigments from the middle palaeolithic levels of es-Skhul (Mount Carmel, Israel). J. Archaeol. Sci. 37 (12), 3099-3110.

Geneste, J.-M., Plisson, H., 1986. Le solutréen de la grotte de Combe Saunière 1 (Dordogne) : première approche palethnologique. Gall. Préhist. 29, 9-27.

Gialanella, S., Belli, R., Dalmeri, G., Lonardelli, I., Mattarelli, M., Montagna, M., Toniutti, L., 2011. Artificial or natural origin of hematite-based red pigments in archaeological contexts: the case of Riparo Dalmeri (Trento, Italy). Archaeometry 53 (5), 950-962.

Godfrey-Smith, D.I., Ilani, S., 2004. Past thermal history of goethite and haematite fragments from Qafzeh Cave deduced from thermal activation characteristics of $110^{\circ} \mathrm{C}$ TL peak of enclosed quartz grains. Rev. d'Archéom. 28, 185-190.

Grogan, K.L., Gilkes, R.J., Lottermoser, B.G., 2003. Maghemite formation in burnt plant litterat east Trinity, North Queensland, Australia. Clays Clay Miner. 51 (4), 390-396.

Guillot, P.-L., Roger, P., Le Pochat, G., 1979. Carte géologique de la France au 1/ $50000^{e ̀ m e}: n^{\circ} 759$, Périgueux (Est). Éditions du BRGM, Orléans.

Hovers, E., Ilani, S., Bar-Yosef, O., Vandermeersch, B., 2003. An early case of color symbolism: ochre use by modern humans in Qafzeh Cave. Curr. Anthropol. 44 (4), 491-522.

Hublin, J.-J., Talamo, S., Julien, M., David, F., Connet, N., Bodu, P., Vandermeersch, B., Richards, M., 2012. Radiocarbon dates from the Grotte du Renne and SaintCésaire support a Neandertal origin for the Châtelperronia. In: Proceedings of the National Academy of Science of the United States of America, vol. 109(46), pp. $18743-18748$.

Iakovleva, L., Djindjian, F., 2005. New data on mammoth bone dwellings of eastern Europe in the light of the new excavations of the Gonsty site (Ukraine). Quat. Int. 126-128, 195-207.

Inizan, M.-L., Redurin-Ballinger, M., Roche, H., Tixier, J., 1999. Technology and Terminology of Knapped Stone. Tech. rep.. CREP, Nanterre.

Jezequel, P., 2001. Étude minéralogique de 116 échantillons en provenance du site préhistorique du coteau de ii La Garenne ii. Saint Marcel (Indre). Tech. rep. BRGM report ANA/CMI/NT/01/154.

Jezequel, P., Wille, G., Beny, C., Delorme, F., Jean-Prost, V., Cottier, R., Breton, J., Dure, F., Despriée, J., 2011. Characterization and origin of black and red Magdalenian pigments from Grottes de la Garenne : a mineralogical and geochemical approach of the study of prehistorical paintings. J. Archaeol. Sci. $38,1165-1172$.

Kuzmin, Y.V., Orlova, L.A., 1998. Radiocarbon chronology of the Siberian paleolithic. J. World Prehist. 12 (1), 1-53.

Lahlil, S., Vignaud, C., Menguy, N., Beck, L., Lebon, M., Menu, M., Paillet, P., 2014. Apports, limites et potentiel des analyses micro-destructives pour l'identification de transformations anthropiques - exemple de la grotte Blanchard. In: P, P. (Ed.), Actes du colloque MADAPCA, nov. 2011, pp. 17-25. PALEO, special issue.

Leroi-Gourhan, A., 1961. Les fouilles d'Arcy-sur-Cure (Yonne). Gall. Préhist. 4, 3-16. Lorblanchet, M., 1999. La naissance de l'Art. Genèse de l'art préhistorique. Éditions Errance, Paris.

Menu, M., Vignaud, C., 2006. La techniqe des peintures de Lascaux. Monumental 2, 98-103.

Nørnberg, P., Schwertmann, U., Stanjek, H., Andersen, T., Gunnlaugsson, H.P., 2004. Mineralogy of a burned soil compared with four anomalously red Quaternary deposits in Denmark. Clay Miner. 39, 85-98.

Philibert, S., 1994. L'ocre et le traitement des peaux : révision d'une conception traditionnelle par l'analyse fonctionnelle des grattoirs ocrés de la Balma de Margineda (Andorre). L'Anthropologie 98 (2-3), 447-453.

Pomiès, M.-P., 1997. Pigments Rouges Préhistoriques: Goethite Chauffée Ou Hématite Nanocristalline Naturelle ? Pierre et Marie Curie. Ph.D. thesis, Université. Paris-6. 
Pomiès, M.-P., Menu, M., Vignaud, C., 1998a. Lascaux, pigments préhistoriques à base d'oxydes de fer : Hématite naturelle collectée ou goethite chauffée ? In: Goupry, J., Mohen, J.-P. (Eds.), Actes du Congrès Art et Chimie : La Couleur.

Pomiès, M.-P., Morin, G., Vignaud, C., 1998b. XRD study of the goethite-hematite transformation: application to the identification of heated prehistoric pigments. Eur. J. Solid State Inorg. Chem. 35, 9-25.

Pomiès, M.-P., Barbaza, M., Menu, M., Vignaud, C., 1999a. Préparation des pigments rouges préhistoriques par chauffage. L'Anthropologie 103 (4), 503-518.

Pomiès, M.-P., Menu, M., Vignaud, C., 1999b. Red Palaeolithic pigments: natural hematite or heated goethite? Archaeometry 41 (2), 275-285.

Pomiès, M.-P., Menu, M., Vignaud, C., 1999c. TEM observations of goethite dehydration, application to archaeological samples. J. Eur. Ceram. Soc. 1605-1614.

Regert, M., 1995. Les matières colorantes, combe saunière 1: rapport de fouille de la campagne de 1995 (unpublished field report).

Renard, C., 2011. Continuity or discontinuity in the Late Glacial Maximum of southwestern Europe: the formation of the Solutrean in France. World Archaeol. 43 (4), 726-743.

Rietveld, H.M., 1969. A profile refinement method for nuclear and magnetic structures. J. Appl. Crystallogr. 2 (2), 65-71.

Salomon, H., 2004. Caractérisation et transformations techniques des matières colorantes dans le Solutréen de l'Ouest de la France. UniversitéParis 1. Mémoire de Master 2 (DEA) "Environnement et Archéologie".

Salomon, H., 2009. Les matières colorantes au début du Paléolithique supérieur : sources, transformations et fonctions, 413 pp. Ph.D. thesis, Université de Bordeaux 1.

Salomon, H., Vignaud, C., Coquinot, Y., Pagès-Camagna, S., Pomiès, M.-P., Geneste, J-M., Menu, M., Julien, M., David, F., 2008. Les matières colorantes au début du paléolithique supérieur. In: Actes du Colloque Science des Matériaux du Patrimoine Culturel, Paris, 6-7 décembre 2007, pp. 17-23. Hors Série, Technè.
Salomon, H., Vignaud, C., Coquinot, Y., Beck, L., Stringer, C., Strivay, D., d'Errico, F. 2012. Selection and heating of coloring materials in the mousterian level of esSkhul, (c.a. 100000 years BP, Mount Carmel, Israel). Archaeometry 54 (4), $698-722$

Salomon, H., Vignaud, C., Aubry, T., Walter, B., Vialou, D., Geneste, J.-M., Menu, M., 2013. Les matières colorantes en contexte solutréen. In: Actes du Colloque: Le Solutréen 40 ans après la publication du Smith'66, Preuilly-sur-Claise (Indre-etLoire), pp. 319-330, 28-31 octobre 2007, 47e Supplément à la Revue Archéologique du Centre de la France.

Salomon, H., Coquinot, Y., Beck, L., Vignaud, C., Lebon, M., Odin, G.P., Mathis, F. Julien, M., 2014. Stratégies spécialisées d'acquisition de pigments rouges duran le Châtelperronien de la grotte du Renne à Arcy-sur-Cure, Yonne, France. In: Paillet, P. (Ed.), Actes du colloque MADAPCA, nov. 2011, pp. 125-133. PALEO, special issue.

Schmidt, P., Masse, S., Laurent, G., Slodczyk, A., Le Bourhis, E., Perrenoud, C. Livage, J., Fröhlich, F., 2012. Crystallographic and structural transformations of sedimentary chalcedony in flint upon heat treatment. J. Archaeol. Sci. 39 (1) 135-144.

Schwertmann, U., Cornell, R., 2000. Iron Oxides in the Laboratory. Wiley.

Tiffagom, M., 1998. Témoignages d'un traitement thermique des feuilles de laurie dans le solutréen supérieur de la grotte du parpalló(gandia, espagne). Paléo 10 $147-161$.

Vignaud, C., Salomon, H., Chalmin, E., Geneste, J.-M., Menu, M., 2006. Le groupe des "bisons adossés" de Lascaux. étude de la technique de l'artiste par analyse des pigments. L'Anthropologie 110, 482-499.

Wadley, L., 2009. Post-depositional heating may cause over-representation of redcolored ochre in Stone Age sites. South Afr. Archaeol. Bull. 64 (190), 166-171.

White, R., 1996. Actes de substance : de la matiére au sens dans la représentation paléolithique. Techné 3, 29-38.

Wreschner, E.E., 1980. Red ochre and human evolution: a case for discussion. Curr. Anthropol. 21, 631-634. 